\title{
Beyond the material: knowledge aspects in seed commoning
}

\author{
Stefanie Sievers-Glotzbach ${ }^{1}$ (1) Johannes Euler ${ }^{2} \cdot$ Christine Frison $^{3} \cdot$ Nina Gmeiner $^{1} \cdot$ Lea Kliem $^{1,4} \cdot$ Armelle Mazé $^{5}$. \\ Julia Tschersich ${ }^{1}$
}

Accepted: 6 October 2020 / Published online: 26 October 2020

(c) The Author(s) 2020

\begin{abstract}
Core sustainability issues concerning the governance of seeds revolve around knowledge aspects, such as intellectual property rights over genetic information or the role of traditional knowledge in plant breeding, seed production and seed use. While the importance of knowledge management for efficient and equitable seed governance has been emphasized in the scientific discourse on Seed Commons, knowledge aspects have not yet been comprehensively studied. With this paper, we aim to (i) to analyze the governance of knowledge aspects in both global and local/regional Seed Commons, (ii) to highlight disconnections in knowledge governance between the local Seed Commons and global governance of plant genetic resources, and (iii) to investigate the contribution of knowledge commoning to environmentally sustainable and culturally adapted food systems. For this purpose, we will analyze knowledge governance by the International Seed Treaty (ITPGRFA) and by two local Seed Commons, a Philippine farmer-led network and a German organic-breeding association. We take the analytical lens of commoning, focusing on social practices rather than specific resources. The main challenges include finding institutional arrangements, which fruitfully integrate aspects from both traditional and scientific knowledge systems, taking into account the complex interrelation between knowledge-related, material and cultural aspects of seeds.
\end{abstract}

Keywords Seed commons $\cdot$ Knowledge governance $\cdot$ Case studies $\cdot$ Plant genetic resources for food and agriculture Commoning

\section{Introduction}

Seeds inevitably combine material and immaterial aspects, such as knowledge and culture (Frison 2016, 2018; Dedeurwaerdere 2012; Halewood 2013). Knowledge aspects - specifically local and practical knowledge held by communities - have always played a major role in the management of seeds (Demeulenaere 2005, 2014; Girard 2018). Core sustainability issues concerning the governance of seeds,

Stefanie Sievers-Glotzbach

stefanie.sievers-glotzbach@uol.de

1 Department of Business Administration, Economics and Law, University of Oldenburg, Oldenburg, Germany

2 Alanus University of Arts and Social Sciences, Alfter, Germany

3 Government \& Law Research Group, Faculty of Law, University of Antwerp, Antwerp, Belgium

4 Institute for Ecological Economy Research, Berlin, Germany

5 Université Paris Saclay, INRA SADAPT, AgroParisTech, Paris, France including agrobiodiversity conservation and food sovereignty, revolve around knowledge aspects, such as intellectual property rights over genetic information (Frison 2018) or the role of traditional knowledge in plant breeding, seed production and seed use.

Variety development and maintenance by farmers depend on the preservation, sharing and intergenerational transmission of traditional local knowledge, mostly in institutional arrangements called "Seed Commons" (Sievers-Glotzbach et al. 2020). Seed Commons describe institutions based on common ownership and forms of collective management in plant breeding and seed production, where a community conducts the handling, growing, breeding, and sharing in a needs-oriented and self-organized way. ${ }^{1}$ While the importance of knowledge management for efficient and equitable seed governance has been emphasized in the scientific

\footnotetext{
${ }^{1}$ Seed Commons arrangements at local and regional scales are characterized by four core criteria: (1) collective responsibility for the protection, provision and development of seeds and crop diversity, (2) protection from private enclosure, (3) collective, polycentric management, and (4) sharing of formal and practical knowledge. For a detailed description and conceptualization see Sievers-Glotzbach et al. (2020).
} 
discourse on Seed Commons, knowledge aspects have not yet been comprehensively studied. Moreover, some types of knowledge appear to be neglected in international seed governance: There is a strong focus on codified, decontextualized knowledge (such as knowledge connected to ex situ collections) compared to the knowledge embedded in seedrelated practices of communities (such as practical breeding skills) (Dutfield 2018; Girard 2018; Louafi and Manzella 2018). This development will likely be further strengthened by current technological developments involving digital sequence information that allows immaterial aspects (genetic codes) to be isolated from their material sources (seeds) and cultural backgrounds. The goals of the paper are thus (i) to analyze the governance of knowledge aspects in both global and local/regional Seed Commons, (ii) to highlight disconnections in knowledge governance between the local Seed Commons and global governance of plant genetic resources, and (iii) to investigate the contribution of knowledge commoning to environmentally sustainable and culturally adapted food systems.

For this purpose, we will first describe how knowledge aspects are considered in the international Seed Commons regime, specifically by the International Treaty on Plant Genetic Resources for Food and Agriculture, and point to strengths and weaknesses of its knowledge governance in promoting food sovereignty ${ }^{2}$ and agrobiodiversity conservation. We will then analyze knowledge governance aspects of two local Seed Commons, which reflect the diversity of Seed Commons arrangements in practice. These are the Philippine farmer-led network MASIPAG and the German organic breeding organization Kultursaat e.V. We take the lens of "commoning" (Euler 2018), focusing on social practices rather than specific resources - thereby doing justice to both the material and immaterial nature of seeds. We adapt and apply the commons conceptualization by Kostakis and Bauwens (2014) as an analytical framework to analyze and compare the knowledge commoning aspects of the two local Seed Commons. Connecting the findings on knowledge governance in global and local Seed Commons, we show that knowledge governance by the Seed Treaty only partially promotes the functioning of local Seed Commons. The main challenges for effective knowledge governance in both local and global Seed Commons are finding institutional arrangements, which fruitfully integrate aspects from both traditional and scientific knowledge systems, taking into account

\footnotetext{
${ }^{2}$ Food sovereignty is a multi-dimensional concept that centers on the self-determination in food production of farming communities, and includes the social control of agricultural means for production, like land, water and seeds (Edelman 2014; Patel 2009).
}

the complex interrelation between the knowledge-related, material and cultural aspects of seeds.

\section{Theoretical background}

The following section describes the relevant theoretical concepts drawn upon in this paper. First, we delineate the historical development and conceptions of commons. Second, we examine the conceptual distinction made in commons studies to investigate material resources (mainly natural resources) and immaterial resources (mainly knowledge). Third, we define Seed Commons and discuss the implications of the material-immaterial divide for their study.

\section{Historical development of commons conceptualizations}

Both the commons themselves and the conceptions used to describe them have been and remain contested. In the Roman Empire four basic types of property were distinguished: res privatae refers to things that were privately held, res publicae to things that were held by the public, meaning the state, res nullis are things held by nobody, and res communes are those things that are shared and cared for by everybody. Current commons conceptualizations stand in the tradition of this last category.

In academia, especially economics, an understanding of commons as open-access goods, unregulated and free to be used by everybody, became mainstream with Hardin's (1968) "tragedy of the commons". The biologist argued that a pasture held in common would inevitably be over-used because each herder has an incentive to put additional cattle on the pasture. The political scientist and institutional economist Elinor Ostrom (1990), who showed that resource users can and do talk to each other and negotiate rules, which allows them to come to long-term sustainable solutions, later rejected this understanding. Ostrom and colleagues focused on the management of natural resources, especially fishery, forestry, irrigation systems, water management and animal husbandry (van Laerhoven and Ostrom 2007; Ostrom 1990, 2009). Ostrom (2010) understood commons as related to common-pool resources: those resources that are characterized by a high degree of subtractability (using the resource reduces its availability to others) and a low degree of excludability (it is hard to exclude others from using the resource). Helfrich (2012) who claims that commons "are created" and do not "simply exist" criticizes this (p. 61). According to this approach, defining commons as goods with certain characteristics (subtractability and excludability) is a false naturalism since what makes something a commons are the social relations rather than the inherent characteristics of the 
good in question (Euler 2018). ${ }^{3}$ For example, the very same water can be used in common, or bottled and sold.

We follow this "practice turn" (Euler et al. 2020) and consider commons as "the social form of (tangible and/ or intangible) matter that is determined by commoning" (Euler 2018 12). ${ }^{4}$ In this view, commons are arrangements of resources or goods that are created and used on the one hand and of specific social processes called 'commoning' on the other hand. Commoning describes social practices of production, usage, care, and administration. They normally occur in user or producer communities (understood in a wide and potentially fluid way) and in many cases they include a high degree of mutual support and cooperation among peers. Euler (2018) defines commoning as "voluntary and inclusively self-organized activities and mediation of peers who aim at satisfying needs" (p. 15). This conceptualization includes the possibility to analyze social practices on a continuous scale (the social practices in question can be commoning to a greater or lesser extent). Additionally, it includes both empirical and normative (or utopian) considerations in the sense that commoning is argued to be only commoning "to full extent" (Euler 2018, 15) in a commonssociety. Finally, the concept of commoning highlights the centrality of social functions, such as democratic participation and autonomy (Euler 2018; Müller 2012; ViveroPol 2017a, b), and has been described as a "political tool and horizon" (Vivero-Pol et al. 2018, p. 8) for orientation towards a social-ecological transformation (Helfrich and Bollier 2019; Nightingale 2019; Sato and Alarcón 2019; Tummers and MacGregor 2019).

\section{Beyond the conceptual dichotomy between the material and immaterial in commons studies}

The work by Elinor Ostrom (1990) points to the importance of knowledge aspects in Natural Resource Commons, such as the relevance of local knowledge for creating collectivechoice arrangements that match local conditions (Ostrom 2009; Cox et al. 2010). However, material and knowledge aspects are mostly considered separately in commons studies. A distinct research field with specific conceptual frameworks on the governance of Knowledge Commons has emerged alongside the study of Natural Resource Commons (Frischmann et al. 2014; Hess and Ostrom 2003; Hess 2012).

\footnotetext{
3 Also Buchanan (1965) and Engel (2002) argue that the degree of excludability of a good is not solely determined by the physical attributes of the good, but varies depending on technical and social circumstances (see also Kliem and Tschersich 2017).

${ }^{4}$ In this sense, everything could be a commons: gardens, elderly care facilities, radio frequencies, transport infrastructures, high-tech factories, songs, seeds, knowledge, etc.
}

According to Frischmann et al. (2014), Knowledge Commons refer to the "institutionalized community governance of the sharing and, in some cases, creation, of information, science, knowledge, data, and other types of intellectual and cultural resources" (p. 3). Examples include the internet, open-source software and Wikipedia, but also earlier, nondigital information such as fairy tales and lullabies. From a conceptual perspective, a major reason for the separation between the material and the immaterial is that knowledge is fundamentally different from natural resources regarding its resource characteristics (Hess and Ostrom 2007; Cole 2014, 5): Knowledge has been discussed to be largely nonsubtractive in use, whereas many natural resources are characterized by high subtractability. Furthermore, Knowledge Commons give greater consideration to processes of collective creation. Hence, distinct collective action problems have been identified in the case of Knowledge Commons, such as the "public-good dilemma" (Heller 1998) and the "tragedy of the anti-commons" (Heller 1998; also Hess and Ostrom 2007), resulting in an underprovision of knowledge (products).

Hess and Ostrom $(2007,12)$ cite historical reasons for the fact that "most of the interdisciplinary work on the Knowledge Commons to date is not an outgrowth of the Natural Resource Commons literature". Firstly, Knowledge Commons have been embedded in the narrative of the "second enclosure movement" (Boyle 2003): the enclosure of the 'intangible commons of the mind' that followed the historical enclosure of collectively managed natural resource systems. Secondly, Knowledge Commons have featured in discussions on openness, inclusiveness and democratic processes, such as the town commons in the United States, which are shared spaces allowing free speech (Hess and Ostrom 2007, 12). This was accompanied by different views on open access: Boyle (2003), in his work on the public domain, and Benkler (2003; 2006), in his early scientific writings on "commons-based production", argued in favor of open, ungoverned access to knowledge, whereas Ostrom (1990) studied common-property institutions for a successfully regulated access to goods and resources.

\section{Seed Commons}

Commons approaches have also been analyzed with regard to the management of seeds and the breeding of new varieties. At the global scale, the collective management of Plant Genetic Resources for Food and Agriculture (PGRFA) in the context of the International Treaty on Plant Genetic Resources for Food and Agriculture (hereafter the Seed Treaty) has been conceptualized as a Global Commons (Frison 2016, 2018; Dedeurwaerdere 2012; Halewood 2013). Moreover, Seed Commons can take the form of traditional seed systems, such as seed saving and seed exchange 
networks, or of more recent organizational arrangements, such as initiatives to conserve landraces or other plant genetic resources, and to develop new, adapted varieties for organic plant breeding (Osman and Chable 2009). In light of the commons theory developed in the "Historical development of commons conceptualizations" Section, (local and regional) Seed Commons are commoning-based arrangements centered on seeds, where a community conducts de facto handling, growing, breeding, and sharing (Sievers-Glotzbach et al. 2020). Local Seed Commons face the problem of integration into public policies and seed legislation, both at local/regional, national and international levels (Coomes et al. 2015; Chable et al. 2020; Demeulenaere 2014).

Both knowledge embedded in seeds (i.e. the genetic code) and knowledge connected to handling seeds (practical local and abstract codified knowledge) are relevant when designing Seed Commons arrangements. Seed Commons are thus 'Hybrid Commons' (Wolter and Sievers-Glotzbach 2019), combining elements of both Natural Resource Commons, Knowledge Commons and commoning (Sievers-Glotzbach et al. 2020).

\section{Knowledge governance in seed commons: the international Seed Treaty}

In the following, we will contrast how knowledge is governed in local and global Seed Commons. For this purpose, we will first give an overview of how knowledge is governed in the Seed Treaty as a global Seed Commons, with regard to three levels of Commons, in particular its institutional structure, the involved community and the governed resource (with a focus on knowledge) (Section Knowledge governance in Seed Commons: the international Seed Treaty). We will reflect on the strengths and shortcomings of the Seed Treaty with regard to how its governance of knowledge contributes to environmentally sustainable and culturally adapted food systems. On this basis, we then focus on two local case studies as alternative ways of managing knowledge governance in local and regional Seed Commons (Section Knowledge governance by two local Seed Commons). We emphasize the central role of commoning in these local and regional Seed Commons, by integrating commoning as a central aspect in our analytical framework (see Section Methodology).

To gain a more detailed understanding of knowledge governance in global and local Seed Commons, it is helpful to distinguish between traditional agroecological and scientific knowledge. According to Calvet-Mir et al. (2018, 3214), traditional agroecological knowledge (TAeK) "refers to the cumulative and evolving body of knowledge, practices, beliefs, institutions, and worldviews about the relationships between a society or cultural group and their agroecosystems". TAeK therefore includes practices, knowledge and beliefs pertaining to the handling of seeds. Such knowledge systems have been contrasted with Western scientific (ecological) knowledge systems (Berkes et al. 2000; Rathwell et al. 2015) even though no clear line can be drawn between the two (see e.g. Agrawal 1995; Weiss et al. 2013). The difference lies in the abstract character and mobility (not embedded in a particular community and local context) of scientific knowledge as well as the assumption of a subject/ object dichotomy (Banuri et al. 1993; Berkes et al. 2000; Mazé et al. 2020).

The following analysis of knowledge governance in the context of the Seed Treaty is based on working documents from the Treaty Secretariat, reports and resolutions of the Governing Body of the Treaty, active participation in the negotiation process (either as negotiator or as observer) since 2004 and five open-ended interviews with members of the Ad Hoc Technical Expert Group on Farmers' Rights (AHTEG-FR) during its second meeting.

\section{The institutional structure of the Seed Treaty}

The Seed Treaty aims at "the conservation and sustainable use of plant genetic resources for food and agriculture and the fair and equitable sharing of the benefits arising out of their use" [hereafter ABS, i.e. access and benefit-sharing] (Treaty Article 1.1). To further these aims, it stipulates rules for the management of seeds on a global scale. The Treaty became operational in the years 2010-2011, once its main tools and mechanisms had been developed and adopted by its Governing Body. To date, there are 146 contracting parties.

To implement the conservation, sustainable use and ABS objectives, several tools and instruments were designed: The Standard Material Transfer Agreement (SMTA) and the Benefit-Sharing Fund (BSF) are the main operationalizing tools of the Multilateral System of Access and Benefit-sharing (MLS). In addition, a range of other instruments such as a Compliance Committee, a funding strategy, a ThirdParty Beneficiary clause and a Global Information System (GLIS) were developed for the implementation of the Treaty, including the obligations deriving from the MLS. For this analysis, the focus will be on the Treaty's knowledge governance in form of the MLS and the related benefit sharing measures. ${ }^{5}$ The MLS (Treaty Articles 10 to 13) functions as a virtual common basket of "seeds", ${ }^{6}$ where "recipients"

\footnotetext{
${ }^{5}$ For further development on the governance of the whole Treaty, see Frison 2016 and 2018.

${ }^{6}$ Seeds here represent the accessions held in genebanks by all Treaty contracting parties, including the information related to the accessions.
} 
(researchers, breeders, farmers) may access PGRFA from "providers" (generally national or international genebanks), using a standard contract (the SMTA) which stipulates specific conditions for access.

\section{Community: MLS stakeholders and their positions}

The Seed Treaty's global Seed Commons community comprises states, national (whether public and private) and international genebanks, and research institutions (e.g. the Consultative Group for International Agricultural Research (CGIAR)), farmers' communities, commercial actors (the seed industry and breeders), as well as non-profit actors (NGOs). However, the primary direct users of the MLS (as providers or recipients of PGRFA) are researchers, breeders and genebanks (Treaty Article 12.3(a)), all of which mainly focus on scientific knowledge.

MLS stakeholders hold heterogeneous positions regarding intellectual property rights (IPRs), conservation strategies, the main technology they apply or their preferred seed exchange networks. Farmers focus on in situ conservation, informal seed networks and the recognition of Farmers' Rights, while the seed industry concentrates on ex situ conservation, strong IPRs, and plays a key role in formal commercial seed markets. These discrepancies explain the ongoing difficulties in reaching the Seed Treaty's objectives in a swift and collaborative way.

The exchange of seeds takes place through the SMTA, a standard contract defining specific and identical conditions of access and use for all users. The MLS and SMTA governance rules are designed by the Governing Body of the Treaty, in which farmers organizations can only participate as observers.

\section{Resource: knowledge and its political impacts on seed systems}

A key objective of the Seed Treaty is the facilitated access to PGRFA (Treaty Article 13.1), which is an essential element in the development and exchange of related knowledge. Fast and easy access is provided for purposes of utilization, conservation for research, breeding and training for food and agriculture (Article 12.3(a)). All available (nonconfidential) information on PGRFA shall be shared in the MLS, including catalogues, research results and information on technologies (Articles 12.3, 13.2). When a product that includes material from the MLS is commercialized and access is restricted, payments to the BSF become obligatory (see below) (Article $13.2 \mathrm{~d}$ ).

Scientific knowledge and technology are considered as essential parts of the benefit-sharing mechanism. The exchange of information, capacity-building and technology transfers (Article 13.2) take place inter alia by providing training on field phenotyping, genome-wide association studies and use of DNA markers, as well as software for data analysis and management (IT/GB-7/17/Inf.5.). The Global Information System was set up to facilitate the exchange of information and knowledge. With its Digital Object Identifier (DOI) project, ${ }^{7}$ it aims to harmonize and facilitate the identification of PGRFA accessions under the MLS for research and breeding purposes (IT/GB-3/09/13 §51). While this is an important objective, this type of information and knowledge is, in its current form, not directly accessible to farmers. Yet, as Halewood et al. (2020) show in this issue, the engagement of farming communities in equitable partnerships with formal sector organizations, such as national genebanks and research organizations, could ease access by farmers to useful planting material in ex situ collections. Also, the Global Plan of Action, incorporated into the Seed Treaty as a supporting element (Article 14), identifies on farm conservation and management as one priority area in the implementation of the Seed Treaty.

Farmers are key in creating, exchanging and managing (traditional) knowledge related to seeds and agricultural practices (Pautasso et al. 2013; Demeulenaere 2014; CalvetMir et al. 2018). The Seed Treaty formally recognizes this important contribution, and acknowledges Farmers' Rights to save, use, exchange and sell seeds. ${ }^{8}$ States are responsible for taking measures to promote and protect these rights, including the protection of TAeK associated with PGRFA. ${ }^{9}$ While more and more countries adopt legislation and policies protecting Farmers' Rights, including their traditional knowledge, this is not recognized as a strong international obligation. ${ }^{10}$

With regard to global ABS benefits, arising from the MLS and collected in the BSF, should flow mainly to farmers who conserve and sustain PGRFA (Article 13.3). Through BSF projects, farmers' communities work in partnership with research institutions, NGOs, or breeders on in situ/on farm conservation activities. ${ }^{11}$ Seeds and related TAeK collected and developed here are then brought back into the MLS system. ${ }^{12}$ However, these activities under the umbrella of the

\footnotetext{
7 See the DOI webpage of the Treaty website https://www.fao. org/plant-treaty/areas-of-work/global-information-system/doi/en/ (accessed on October 27, 2019).

${ }^{8}$ See preamble; Article 9 on Farmers' Rights.

${ }^{9}$ See Art. 9.2 a on responsibility of states and the importance and protection of traditional knowledge more specifically.

10 IT/GB-8/AHTEG-FR-2/19/3.

11 According to their website, the BSF "prioritises on farm management and conservation, it increases food security and facilitates innovative partnerships." https://www.fao.org/plant-treaty/areas-ofwork/benefit-sharing-fund/projects-funded/en/ (accessed October 27, 2019).

12 i.e. if new varieties are developed or characterized, they are included in the MLS and the GLIS; IT/GB-7/17/Inf.5 at $\$ 25$.
} 
global Seed Commons concern a small number of projects (72 projects over 10 years through 4 cycles of funding) with limited funding (only just over USD 28.000 .000 of the initial target USD 116.000.000). Most projects supporting farmers' traditional knowledge and seed networks take part in national projects and policies. ${ }^{13}$

In the Seed Treaty, the interface between knowledgerelated (immaterial) and material aspects in seed governance is a delicate question. There are ongoing discussions about whether digital sequence information (DSI) falls within or outside the scope of the MLS. DSI covers "the information and knowledge content of genetic material [that could be] extracted, processed and exchanged in its own right, detached from the physical exchange of the plant genetic material" (FAO, IT/GB-5/13/4). Whether DSI is considered part of the genetic material under the MLS, has an impact on the way knowledge is perceived and governed in relation to the material aspects of seeds (MLS accessions), and influences where money and implementation efforts are invested (e.g. GLIS-DOI project, DivSeek project ${ }^{14}$ ). If DSI extracted from MLS material is considered outside the scope of the MLS, then no related ABS obligations are applicable to subsequent transfers, thereby circumventing current ABS obligations. This might reinforce the divide between TAeK, perceived as non-innovative, and biotech-related "scientific" information, perceived as the type of knowledge that enables seed improvement and adaptation to be taught to farmers' communities. $^{15}$

Overall, it becomes visible that both TAeK and scientific knowledge are considered within the Seed Treaty. The protection of TAeK is especially recognized as part of Farmers' Rights; however, it is left to the national level to implement these. Nevertheless, farmers are clearly identified as the target group for receiving support from benefit sharing. While participatory plant breeding projects funded through the BSF enable the integration of farmers as knowledge cocreators, these projects are restricted by the limited funds available in the BSF. The MLS is very successful in facilitating access to PGRFA for research, breeding and training (Tsioumani 2018); yet farmers are not direct beneficiaries.

\footnotetext{
13 see the inventory of measures for the realization of Farmers' Rights, IT/GB-8/AHTEG-FR-2/19/3.

14 Treaty Resolutions 3/2015 and 8/2015; see also IT/GB-8/19/10/ Inf. 2 and IT/GB-7/17/15. On the conflictual role of DivSeek in the Treaty, read https://www.terranuova.org/news-en/the-divseekinitiative-and-the-international-treaty-on-plant-genetic-resources (accessed October 27, 2019).

15 It must be noted that the term knowledge is only used in relation to the term traditional. When it comes to PGRFA under the MLS, catalogues and inventories, information on technologies, results of technical, scientific and socio-economic research are all classed as under the term (scientific) information to be shared through the GLIS (IT/ GB-6/15/7 at $\$ 10)$.
}

Moreover, the MLS and Global Information System privilege scientific information, and material is made available using processes and tools most relevant for researchers and breeders, which are difficult to access for farming communities. This complicates the cultural and social mechanisms of knowledge transmission between farmers' communities and other stakeholders. Consequently, the described mechanisms provide only a limited direct use value for farming communities. ${ }^{16}$

\section{Shortcomings with regard to realizing food sovereignty and agrobiodiversity}

The Seed Treaty addresses plant genetic resource issues for a large and global community. However, research organizations, genebanks and seed companies are the main users of the MLS (Galluzzi et al. 2016), and nation states the central actors in decision-making. While the Seed Treaty formally recognizes small-scale farmers' relevance in the generation and conservation of genetic resources, and in the management of knowledge relating to seeds, the Treaty does not include sufficient instruments to ensure the access and active participation of farmers for instance in the MLS, or compliance in implementation of Farmers' Rights on the national level. Though farmer communities are supported through projects aimed at conservation and participatory breeding funded by the BSF, a more active role of farmers as active innovators as part of the MLS, an enhanced (direct) integration in deliberation processes of the Treaty, and a better integration of TAeK could enhance the contribution of the Seed Treaty to food sovereignty.

\section{Knowledge governance by two local Seed Commons}

In how far can local Seed Commons initiatives address the shortcomings identified in the knowledge governance by the Seed Treaty? This section investigates knowledge governance by an in-depth study of two local Seed Commons. Before presenting the cases and empirical findings, we develop a set of analytical criteria to investigate knowledge governance in different local and regional Seed Commons arrangements.

\footnotetext{
${ }^{16}$ Of course, farmers can indirectly benefit from research on in situ conservation and new varieties developed through the use of material from the MLS, when they are made freely accessible.
} 


\section{$\underline{\text { Analytical framework }}$ \\ Community \\ - Characterization of community \\ - Role of farmers and breeders in knowledge creation and transfer \\ Resource: Knowledge \\ - Relevance and mobilization of traditional agroecological knowledge \\ - Relevance and mobilization of scientific ecological and formalized (legal) knowledge \\ - Relation between knowledge and material aspects in seed governance \\ Social and environmental use values \\ - Use value for individual farmers / breeders \\ - Contribution to environmentally sustainable and culturally adapted food systems \\ Knowledge commoning \\ - Extent of "voluntary and inclusively self-organized activities and mediation of peers who aim at satisfying needs" in social practices at hand"}

Fig. 1 Analytical categories for analyzing knowledge governance in Seed Commons arrangements (Own compilation)

\section{Methodology}

Local and regional Seed Commons differ from the Seed Treaty with regard to their emphasis on social practices of commoning (see Section Seed Commons).To analyze knowledge governance in local Seed Commons and its interlinkages with material aspects, we thus use a distinct analytical frame, the framework by Kostakis and Bauwens $(2014,39)$ and adapt it with respect to the focus on seed/ knowledge commoning. The framework can be applied to the collective governance of both material and immaterial goods. Thus, it allows us to study the governance of knowledge aspects in their interaction with material aspects. Thereby we can overcome the material-immaterial divide in Commons studies (see Section Beyond the conceptual dichotomy between the material and immaterial incommons studies). Furthermore, Kostakis and Bauwens $(2014,39)$ view commons as social processes; this demonstrates the compatibility of the intended application of their commons conceptualization with our definition of Seed Commons as practices of commoning (see Section Seed Commons).

Kostakis and Bauwens $(2014,39)$ structure the analysis of commons arrangements around four interlinked components: (i) resource, (ii) community which shares it, (iii) use value created through social reproduction or preservation of the resource as a common good, and (iv) rules and property regimes that govern people's access to the resource. We specify relevant aspects of those four components for our analysis: According to the focus on social practices instead of institutional analysis we replace point (iv) with knowledge commoning (see Fig. 1). Additionally, we adapt and specify the components with regard to their applicability to the special case of Seed Commons.

We will analyze two cases that reflect the diversity of local Seed Commons and their knowledge commoning in practice. The first is MASIPAG, a Philippine farmerled network, which includes community seed banks, seed exchange practices and farmer-led breeding of locally adapted rice cultivars. TAeK is of high relevance for this community of the Global South. The second case study describes Kultursaat, a German association of farmerbreeders, which breed organic vegetable varieties on farm and makes them accessible to farmers and breeders without claiming variety protection. To describe the knowledge governance in these local Seed Commons, we collected and analyzed qualitative data. For MASIPAG eight semi-structured interviews with farmers and staff were carried out during a research visit in 2019, supplemented by daily minutes from a weeklong workshop during that time. For Kultursaat, ten semi-structured interviews were conducted in 2018, with both breeders and coordinators of the organization. These interviews were complemented by minutes on the association's biannual meetings in 2017 and 2018, where the researchers were present as observing participants, and by Kultursaat's own brochures and online self-presentation. 


\section{Farmer-led breeding in the Philippines: The case of MASIPAG}

\section{Community}

Characterization of community (actors involved, seed activities, core governance elements, structure of the social network) MASIPAG is a farmer-led network in the Philippines consisting of over 30.000 farmers and farmer-breeders, as well as scientists and non-governmental organizations (MASIPAG 2019). The organization was founded in the 1980s and is financially supported by European nongovernmental organizations to employ a necessary minimum of staff. The network's goals are to improve the livelihood of small-scale farmers and sustain agrobiodiversity. Its main conservation and breeding efforts are directed towards rice, but they also breed corn, poultry and other farm animal species. To date, MASIPAG's national backup farm (BUF), where all of their varieties are collected and regularly replanted, holds over 2.500 rice varieties - traditional varieties and new varieties bred by MASIPAG's farmers and scientists. To join MASIPAG, farmers have to organize to form independent People's Organizations (POs), with about ten to fifteen members each. The POs are completely independent in their decision-making and agenda setting, as long as they comply with MASIPAG's core values. This gives MASIPAG a polycentric structure. ${ }^{17}$ Each PO sends a representative to meetings of Provincial Consultative Bodies (PCBs), the basic unit of MASIPAG. They additionally organize in regional and national committees, which meet regularly. This allows knowledge to be dispersed throughout the organization. Each meeting includes informal seed exchanges and agricultural knowledge sharing.

Role of farmers and breeders in knowledge creation and transfer Small-scale farmers, who autonomously conserve rice varieties, are at the heart of the network. More experienced MASIPAG farmers conduct training programs for new POs to share their knowledge, skills and attitude. This training spans a range of topics, from organic farming knowledge to rice breeding. Their common ground is to promote a "farmer-scientist" approach, where farmers learn to develop new farming knowledge by structured observation and thereby gain autonomy. While this primarily falls under TAeK in the creation process, the semi-professional formalization and dissemination leans toward scientific knowledge.

\footnotetext{
17 Here, polycentricity is understood as governance of multiple, interdependent but formally independent centers of decision-making (Ostrom 2010; Ostrom, Tiebout, and Warren 1961).
}

Seeds and knowledge are managed and exchanged both formally, by staff and backup farms, and informally, through seed exchange practices and decentralized knowledge creation (resource knowledge and participatory property regime). The POs each maintain a trial farm with at least 50 landraces, where they screen rice varieties for their adaptability to local environmental conditions and report findings back to the BUF. In this way, farmers create new knowledge for themselves and the network.

\section{Resource: knowledge}

Relevance and mobilization of traditional agroecological knowledge Both TAeK and scientific knowledge are collected and developed by MASIPAG's farmers and volunteering scientists. Small-scale Filipino farmers have little scope for monetary advantage, so knowledge is a prime resource of the network. To make it available to MASIPAG's members, structures have been developed to formalize relevant (traditional) ecological knowledge. For example, newly developed farming techniques are recorded by area coordinators through a formalized scheme (FDATDocumentation and Dissemination of Farmer Developed/ Adapted Technologies), and rice knowledge is centralized and professionalized through the Collection, Identification, Maintenance, Multiplication and Evaluation (CIMME) programme. On an individual level, the farmer-scientist and farmer-led breeding approaches encourage critical reflection on everyday farming tasks and make formerly tacit knowledge explicit for farmers and thereby shareable. The prime example for this is the experimental approach to seed saving and breeding applied in the PO-managed trial farms. Not only farming and breeding knowledge are deemed relevant, however, but also social (cooperation, negotiation), organizational and political-tactical knowledge. Traditional knowledge also includes beliefs and practices (Reyes-Garcia et al. 2018). An important belief of MASIPAG is that seed is sacred and therefore should not be sold, but shared and kept accessible to farmers.

Relevance of scientific ecological and formalized (legal) knowledge Scientific knowledge is used for internal professionalization and as a tool for political positioning at national level. For this purpose, scientific studies about MASIPAG and Philippine rice farming are collected and research cooperation is welcomed on MASIPAG's terms. At the same time, formalization of knowledge is experienced as a threat to MASIPAG's goals in some instances. For example, the network refrains from including their varieties in local and national seed registries. As mentioned above, most of MASIPAG's knowledge is semi-formalized and can thus be seen as semi-scientific. It goes beyond the confined local scope of TAeK, while acknowledging its contextual embed- 
dedness: practices are never copied as blueprints from one PO to another, but are always carefully adapted to specific, local conditions.

Philippine seed legislation does not require MASIPAG to register its varieties in order to disseminate them through non-monetary sharing and exchange. The network has therefore decided to keep its seeds unregistered to serve as an alternative to the formal seed system, with as little connection as possible to this regime. For the same reason, the term variety is not used by MASIPAG staff and members, as it describes a registered, narrow population of plants which comply to formalized legal criteria. Instead, they talk only about seeds.

Relation between knowledge and material aspects in seed governance Knowledge aspects link directly to material and cultural features of MASIPAG's Seed Commons. They often reinforce each other. For example, MASIPAG is careful to protect seeds from appropriation. Both intellectual property rights and breeding methods that limit the reproducibility of varieties can serve as instruments to limit farmers' autonomy, as these instruments individualize knowledge. For this reason, the network is careful to restrict external access to their seeds and seed knowledge, and refuses genetic registration of their landraces in international databases. It does not send seeds to national or international genebanks, even when these institutions request them.

Seed are sacred and must not be sold is the main principle of the network. Whenever material seeds are given to nonmembers, they are given an "orientation", which imparts MASIPAG's core values of sacred seed and organic agriculture and knowledge on seed saving. By making this a mandatory practice, MASIPAG reconnects seed knowledge with (physical) seeds. Within the organization, each meeting on all levels serves as a formal and informal seed and knowledge exchange. By practicing this, farmers recreate and consolidate a seed sharing culture.

\section{Social and environmental use values}

Use value for individual farmers/ breeders The network's goals are to sustain rice diversity and improve the livelihood of small-scale farmers (use value). MASIPAG farmers regain control over agricultural inputs and farming knowledge by preserving, sharing, collecting and breeding rice landraces. This is especially crucial in light of the financial and social constraints small-scale farmers face in the Philippines, as mentioned above. Once farmers have shifted to organic production for their main crop (in most cases rice), MASIPAG teaches them to implement diversified and integrated farming systems (DIFS) to achieve food security and greater resilience to the vagaries of market and climate. This strategy of farmer-led sustainable agriculture has proven successful in increasing food security and diet diversification for farmers, along with a more diverse selection of planted crops and improved health (Bachmann et al. 2009).

Support for environmentally sustainable and culturally adapted food systems MASIPAG's seeds are specifically adapted to organic farming systems and are assessed by farmers for their tolerance to climate-change-related stresses. They thereby contribute to conserving agro-biodiversity, supporting food sovereignty, climate resilience and environmental sustainability. MASIPAG's most important variety preservation mechanism is the nationwide distribution of as many landraces as possible to as many POs as possible. The POs, in turn, choose or breed varieties adapted to their local conditions and cultural preferences.

\section{Knowledge commoning}

Can MASIPAG's practices be understood as (knowledge) commoning? First, all farmers join the network voluntarily. As the network is large, self-organization is organized in various governance levels. By encouraging farmers to establish POs rather than participating in the network's Seed Commons individually, smaller communities are created where every farmer directly engages in self-organization and mediation on eye level with peers. The trial farms serve to satisfy farmers' needs: find suitable varieties for their region and obtain knowledge on how to reproduce quality seeds for their own fields. The social practices which shape MASIPAG can therefore be understood as commoning. The remainder of the paragraph goes deeper into how their commoning is linked to knowledge.

Commoning is in visible three principles, which are pillars of the network's success: individual autonomy, community resilience and the protection of seeds from privatization. MASIPAG emphasizes the value of autonomy to ensure and improve the livelihoods of small-scale Filipino farmers. Materially, this means striving for individual and communal self-sufficiency in agricultural inputs (such as on farm production of organic seed, organic fertilizers and pesticides). Furthermore, sharing is a central practice to create polycentric resilience in case seeds are lost in one region due to natural calamities. A precondition for this autonomy is farmers' continual improvement of farming and seed saving knowledge.

MASIPAG's success is grounded in the creation of POs as communities. Knowledge is made explicit through discussions of farming practices and technology in training sessions, and later in group meetings. This transparency is a precondition for further autonomous, structured, and reflective group learning, supported by the self-concepts of farmer-scientists and farmer-led breeding. These tightly linked groups ensure community resilience through the 
exchange of materials (seeds), cultural services (community work), and knowledge resources (trial farms, sharing of best practices).

As mentioned above, MASIPAG is careful to protect seeds from appropriation to ensure long-term self-organization. Varieties are bred with methods which preserve the plants' ability for reproduction and intellectual property rights are waived. Finally, MASIPAG does not formally register seeds, because its members believe that free access to seeds is part of Farmers' Rights. At the same time, sharing MASIPAG varieties with small-scale farmers outside the network is a common practice. As seeds tend to be (materially) a non-rival good, decisions about sharing seeds with outsiders are left to the farmers.

\section{Developing organic varieties: the case of Kultursaat e.V.}

\section{Community}

Characterization of community (actors involved, seed activities, core governance elements, structure of the social network) Kultursaat e.V. is an association of independent biodynamic vegetable breeders based in Germany. The association formed in 1994 with the aim of increasing the diversity of varieties through breeding and promoting openpollinated varieties, specifically suited for organic farming conditions. Kultursaat breeds varieties for both commercial and hobby gardeners. Today, the association has more than 90 new and 19 conservation varieties registered with the German Federal Plant Variety Office. These have been bred by over 30 independent breeders (Kultursaat e.V. 2017). The initiative is organized in a decentralized network structure with breeders working on farms in Germany, the Netherlands, and Switzerland. The community employs polycentric governance structures, characterized by flat hierarchies, collective decision-making, and considerable autonomy for the individual breeders. Their shared purpose, objectives and values are laid out in the organization's guiding principles (see Kultursaat e.V. 2018). Kultursaat works closely with Bingenheimer Saatgut AG, a seed company that multiplies and markets organic varieties, including Kultursaat varieties, to farmers and gardeners. The company's shareholders are mainly farmers, including many Kultursaat breeders. This close cooperation facilitates knowledge integration along the value chain. A guiding principle of the association is that varieties are seen as cultural assets and common goods which should be managed collectively (Kultursaat e.V. 2019a). This has consequences for Kultursaat's organizational structure, including the governance of knowledge and collective learning processes.
Role of farmers and breeders in knowledge creation, and transaction All breeders in the network are trained farmers or gardeners, and often primarily earn their income through biodynamic horticultural cropping. Their practical knowledge on vegetable cultivation is an integral part of their breeding expertise. Breeders organize themselves in smaller working groups on specific vegetable crops and are experts on these cultures within the association. As such, they have substantial scope for decision-making and agenda-setting. It is assumed that, over time, farmers develop a so-called breeders' eye for the crops and varieties they have worked with intensively. This refers to the expertise and intuition farmers develop to identify plants with promising characteristics in the process of selection.

\section{Resource: knowledge}

Relevance and mobilization of traditional agroecological knowledge Kultursaat breeders consider varieties to be cultural goods, in which the knowledge and practice of generations of farmers and breeders is accumulated. Breeding as a collective practice therefore entails a social and cultural responsibility. Following this tradition, Kultursaat members breed open-pollinated varieties, which can be maintained on-farm and whose seeds can easily be saved by farmers for future growing seasons. Besides contributing to the independence of farmers, who do not need to purchase new seeds each year, these varieties can be used as starting points for future breeding processes. The development of openpollinated varieties relies on breeding techniques that have been traditionally practiced by farmers, such as crossing and selection. Kultursaat encourages its members to get to know the cultural value of traditional practices and related values and norms. The association has made a conscious decision against modern breeding techniques that interfere with the integrity of plants, such as hybrid breeding, genetic engineering or genome editing (Kultursaat e.V. 2018).

Relevance of scientific ecological and formalized (legal) knowledge The work of Kultursaat e.V. is grounded in the scientific understanding of the ecological benefits of organic farming practices and the threats for agriculture associated with climate change. Scientific ecological knowledge is integrated into breeder training and is specifically relevant in the context of breeding projects carried out in cooperation with research institutions such as universities. However, in addition to scientifically validated knowledge and methods, Kultursaat also encourages spiritual and antroposophic practices such as eurythmy and meditative practices (Kultursaat e.V. 2019a).

Knowledge on breeding, agrobiodiversity conservation and political developments is disseminated throughout the network via informal as well as formal channels. Knowledge 
management is formalized using an online database with detailed information on varieties, the breeding process, parent varieties and cultivation practices. The information is shared (remotely) within the network of breeders and variety biographies are freely accessible on the association's website (see Kultursaat e.V. 2019b). Making this information transparent, is not a common practice in the seed industry. Institutionalized forms of knowledge exchange occur through regular multi-day collective meetings, which include farmvisits, trainings and presentations on agricultural and political topics. The association also runs a two-year part-time training program for new breeders, which allows members to pass on both theoretical and practical breeding expertise between generations of breeders (Kultursaat e.V. 2019c).

Relation between knowledge and material aspects in seed governance In the European Union, it is mandatory to register any commercially grown varieties. The registration of newly developed varieties has consequences for materiality. Variety registration demands a high degree of uniformity, which-according to the International Union for the Protection of New Varieties and Plants (UPOV) convention (see UPOV TG/1/3) — depends on the pollination type (self and cross-pollinated) and the cycle of reproduction (e.g. open pollinating and F1 hybrid). Further, the polycentric structure of Kultursaat, including decentralized breeding locations, integrates material and informational aspects: site-specific agroecological knowledge is needed in order to breed locally adapted varieties. In the long-term, the initiative thus contributes to the conservation, promotion and further development of both agrobiodiversity and traditional knowledge on breeding methods.

\section{Social and environmental use values}

Use value for individual farmers/ breeders The network supports farmers and breeders in their efforts to develop new varieties. The funding individual breeders receive through Kultursaat allows them to carry out breeding projects that would otherwise not be financially viable. Furthermore, the network's high degree of formal and informal knowledge exchange supports breeders in building up knowledge and expertise in the development and conservation of varieties. The focus on open-pollinated varieties also decreases farmers' and breeders' reliance on agribusinesses and thereby contributes to their autonomy.

\section{Contribution to environmentally sustainable and culturally} adapted food systems Kultursaat supports the development of sustainable food systems through its focus on organic varieties and the diversification of plant genetic resources. Given the limited number of varieties specifically bred for the organic sector, and the even smaller number of varieties bred under organic conditions (Wilbois and Messmer 2016), Kultursaat breeders aim to address this gap by exclusively breeding varieties specifically adapted to organic cultivation practices (Kultursaat e.V. 2018). Furthermore, to address the future challenges of climate change, the association emphasizes the need for a broad genetic basis and regionally adapted varieties. Varieties developed by Kultursaat breeders are cultivated and tested at various locations and bred on-farm under biodynamic cropping conditions (Kultursaat e.V. 2019a). This requires breeders to have regional and site-specific knowledge about the environmental conditions under which the cultivars they work with flourish.

\section{Knowledge commoning}

Kultursaat's social practice largely fulfills the characteristics of commoning. It is an association of independent breeders who voluntarily joined together to self-govern their breeding efforts. By forming a decentralized network structure, Kultursaat aims to keep flat hierarchies. In annual meetings and working groups focused on specific crops, decisions on finances, organizational matters and breeding goals are discussed and taken collectively. Social practices are guided by values of trust, transparency, appreciation and respect. The Kultursaat breeders aim to serve the need for an independent organic agricultural sector, by developing varieties that are coherent with the values of organic agriculture and meet the specific breeding goals and trait needs of organic cultivations systems.

How does Kultursaat engage in (knowledge) commoning? First, Kultursaat protects seeds from appropriation through rejecting private property rights over varieties. No legal variety protection is claimed for new varieties, i.e. the members of the initiative wave any royalties and make their varieties freely available. Kultursaat registers its varieties to its nonprofit association (legal person) rather than to individual breeders (natural person) or third-party companies in order to limit appropriation and ensure free access to the varieties and the knowledge connected to the breeding process (Kultursaat e.V. 2018).

Second, the regular meetings of the association cultivate a strong sense of community amongst its members, contributing to informal knowledge exchanges on breeding and seed production. These foster the long-term circulation of TAeK within the network. Kultursaat's understanding of the link between knowledge, intellectual property rights and varieties and seeds as material goods, leads the organization to adopt a practice of seed governance where newly bred open-pollinated varieties fall under collective responsibility and knowledge on both the breeding process and variety characteristics is openly shared. While the dissemination of knowledge is not a central aim of the initiative, the network encourages collective learning and empowers individual 
farmers and breeders to contribute to a growing base of knowledge and varieties.

Third, the polycentric structure of Kultursaat, including decentralized breeding locations and decision-making capacities, contribute to knowledge commoning: sitespecific agroecological knowledge is drawn upon to breed locally adapted varieties and autonomous decision-making structures allow to attend to local environmental and social circumstances flexibly.

Just like MASIPAG, Kultursaat thus allows for individual autonomy, fosters a strong network of knowledge exchange, and protects seeds and knowledge from privatization. As such, Kultursaat's approach to (knowledge) commoning contributes to the conservation, promotion and further development of both agrobiodiversity and (traditional) agroecological knowledge on seed production and breeding.

\section{Discussion}

In the following, we discuss the results from investigation of knowledge governance in local and global Seed Commons arrangements. First, we compare the two local Seed Commons MASIPAG and Kultursaat with regard to the categories of analysis. Second, we discuss the impact of knowledge governance by local and global Seed Commons on environmental and social use values.

\section{Knowledge commoning in local seed commons}

The analysis above shows that the communities of MASIPAG and Kultursaat are slightly different. While in both cases farmers and their knowledge play an important role, the emphasis with regard to knowledge creation, breeding and decision-making is on small-scale farmers within MASIPAG and on farmer-breeders for Kultursaat. In both cases, farming and breeding are closely interlinked. MASIPAG farmers are trained as breeders and Kultursaat breeders are simultaneously active as professional farmers. Both initiatives have a polycentric organizational structure, giving substantial agenda-setting and decision-making power to the individual breeders and working groups (for Kultursaat) and to the groups of farmer-breeders organized in People's Organizations (for MASIPAG). In both cases, the overarching goals and values are agreed upon at community-level. MASIPAG has a much larger network and overall structure, consisting of more than 30.000 farmer-breeders, as well as scientists and NGOs, organized on several governance levels. For Kultursaat, the breeding community and the user community are distinct, since the Kultursaat breeders develop new organic varieties mainly for commercial farmers who neither breed themselves, nor are members of the association. For MASIPAG, there is no separation between the breeder- and user community, since the main activities of seed exchange, farmer-led breeding and cultivation of seeds are strongly connected and are carried out by MASIPAG members.

The understanding that knowledge and culture are deeply embedded in seeds and the collective practices of seed sharing (MASIPAG) and breeding is fundamental for both local Seed Commons. This is reflected in the belief of MASIPAG that seeds and rice are sacred and Kultursaat's view of varieties as cultural heritage. Both initiatives integrate traditional and scientific knowledge to a certain extent, but highlight the important role of practical and traditional knowledge. For MASIPAG, the focus is clearly on TAeK, which is formalized and standardized in semi-scientific processes. Kultursaat employs traditional breeding practices, such as crossing and selection, while simultaneously integrating scientific breeding knowledge (genetics) and scientific (ecological) knowledge in the context of organic farming practices and climate change adaptation.

Both Seed Commons initiatives aim at improving seed sovereignty and reject the use of private intellectual property rights to seeds and varieties. They recognize the collective practices and knowledge of farmers and breeders that are embedded in seeds. Furthermore, both organizations share traditional and scientific knowledge within their communities. There is, however, an important difference between the two Seed Commons in their interaction with external actors. MASIPAG is strictly opposed to any commercialization of seeds and does not register varieties to protect both the knowledge and the material from enclosure by the formal system. Seeds (the material) are only shared with farmers outside of the community in conjunction with training that conveys the corresponding knowledge and MASIPAG's values. By contrast, Kultursaat registers its varieties in order to be able to formally market them and reach commercial organic farmers. Kultursaat also freely shares related (formal) knowledge on the varieties. These two distinct strategies are partly due to differences in seed legislation between Germany and the Philippines.

In both Seed Commons initiatives, their polycentric organizational structure supports in situ conservation and on farm breeding at various locations with different biophysical characteristics. The phenotypic selection of varieties and landraces ties knowledge generation and transmission processes to the materiality of seedlings and their interaction with environmental factors. For MASIPAG, this is supported by not registering their varieties, so that seeds can adapt to local environmental conditions and their own needs without having to adhere to specific standards of the formal seed sector. By contrast, variety registration affects Kultursaat's breeding objectives, since varieties have to fulfill high demands regarding distinctness, uniformity and stability. 
Both initiatives contribute significantly to social and environmental use values, in particular to in situ conservation, food sovereignty and the further development of (plant genetic) diversity through the development of culturally and environmentally adapted varieties. While for Kultursaat, the focus is on organic breeding and developing varieties that are suitable for organic agriculture, the core purpose of MASIPAG's work is to improve the livelihood of small-scale farmers. Both initiatives support the autonomy of farmers and breeders, while Kultursaat additionally aims at greater autonomy for the organic vegetable sector as a whole. The goal is to strengthen this autonomy by providing access to knowledge and seeds, and developing seeds that can be reproduced on the farm or used as inputs for further breeding.

\section{Impact of local and global knowledge governance on environmental and social use values}

The two local case studies show that knowledge governance has significant effects on environmental and social use values. In both cases, the rejection of intellectual property rights to varieties broadens overall access to seeds and their embedded knowledge. In the case of Kultursaat, the high level of transparency regarding variety characteristics and parent varieties supports the wide use and further development of these varieties as well as collective efforts for agrobiodiversity conservation. Moreover, varieties are freely available on the market, although registration standards might somewhat limit their genetic heterogeneity, as discussed above. In the case of MASIPAG, because of the risk of enclosure, the diversity of knowledge and seeds is mainly available within the community.

In both initiatives, the internal communal systems of knowledge management and exchange and the training programs allow traditional knowledge and breeding techniques to be enhanced and passed on within and among generations of (farmer-)breeders. Moreover, traditional practices are maintained through formal and informal practices of seed sharing (MASIPAG) and breeding (both organizations). In MASIPAG, the farmer-led training programs and the systematization of traditional knowledge empower farmers and give them autonomy. Their polycentric organizational structure and their focus on contextualized (localized and sitespecific) knowledge allows for the development of regionally and culturally adapted seeds.

The Seed Treaty aims at the promotion of food and seed sovereignty, by formally acknowledging Farmers' Rights as well as the important contribution of smallholder communities, and their TAeK, in sustaining and developing PGRFA. By supporting facilitated access to PGRFA, the MLS aims at improving the global exchange, agricultural use and further development of plant genetic diversity. Farming communities should be able to benefit from direct access to PGRFA and their related information to enhance the genetic base for on farm breeding in their agricultural systems. In practice, however, except from the BSF projects, various obstacles hinder farming communities from participating in and benefiting actively from the MLS. In particular, while the MLS supports the exchange of information, its focus is on scientific knowledge rather than TAeK, which complicates access by farmers. Halewood et al. (2020) in this issue show that partnerships of farming communities with their national gene banks and research organizations can facilitate farmer communities' access to PGRFA managed by the MLS.

\section{Conclusion}

This investigation has revealed the importance of knowledge aspects for the functioning of Seed Commons at both at global and local levels, and the manifold and complex interrelations between informational, material and cultural aspects in their governance. Specifically, we have identified TAeK to be crucial for achieving food sovereignty and maintaining plant genetic diversity in local Seed Commons. As sharing and transmitting TAeK is largely dependent on local social mechanisms, the lens of commoning has proven to be a fruitful approach.

The two cases of local Seed Commons investigated here differ in their main governance objectives: MASIPAG's primary goal is the empowerment of farmers, whereas Kultursaat primarily aims at developing organically-bred varieties for organic agriculture. This becomes apparent in different methods of knowledge creation, sharing and application. MASIPAG's focus is on supporting the knowledge of farmers to develop adapted seeds and sharing this knowledge within the community. Kultursaat integrates existing knowledge (both traditional and scientific) to develop organic varieties. Kultursaat places its varieties on the market and openly shares information on the breeding process and variety characteristics, thereby making them available for a wider user community.

Regarding the integration of local Seed Commons into the global governance of PGRFA, we found that the knowledge governance structures by the MLS pose obstacles to farming communities from directly accessing PGRFA for on farm breeding and also from actively participating in the MLS. Therefore, more implementation resources and efforts should be dedicated to strengthening farmers in their role as knowledge co-creators and by better integrating ex situ and in situ conservation measures.

More generally, our investigation of Seed Commons points to the relevance of knowledge aspects across diverse Natural Resource Commons. While natural resources, 
such as seed samples, may easily be shared and exchanged between diverse communities of actors, the transmission of related knowledge between diverse groups may be limited by various factors, including the distinct characteristics of TAeK and scientific knowledge. Further research could more systematically investigate the knowledge layer of Natural Resource Commons and its connection to the governance of the material goods. The paper demonstrates that commoning can be a suitable theoretical concept for analyzing material and knowledge aspects in their interrelation and regarding their contribution to specific sustainability goals, such as food sovereignty and biodiversity conservation.

Acknowledgements We would like to thank Martin Fredriksson, Anja Christinck, and two anonymous reviewers for their detailed and helpful comments.

Funding Open Access funding enabled and organized by Projekt DEAL. Funding for the research was provided by the German Federal Ministry of Education and Research (BMBF), as part of the program on 'Research for sustainable development' (FONA); Funding reference: 01UU1602A/C

\section{Compliance with ethical standards}

Conflicts of interest The authors declare that they have no conflict of interest.

Open Access This article is licensed under a Creative Commons Attribution 4.0 International License, which permits use, sharing, adaptation, distribution and reproduction in any medium or format, as long as you give appropriate credit to the original author(s) and the source, provide a link to the Creative Commons licence, and indicate if changes were made. The images or other third party material in this article are included in the article's Creative Commons licence, unless indicated otherwise in a credit line to the material. If material is not included in the article's Creative Commons licence and your intended use is not permitted by statutory regulation or exceeds the permitted use, you will need to obtain permission directly from the copyright holder. To view a copy of this licence, visit http://creativecommons.org/licenses/by/4.0/.

\section{References}

Agrawal, Arun. 1995. Dismantling the Divide Between Indigenous and Scientific Knowledge. Development and Change 26: 413-439. https://doi.org/10.1111/j.1467-7660.1995.tb00560.x.

Bachmann, Lorenz, Elizabeth Cruzada, and Sarah Wright. 2009. Food Security and Farmer Empowerment. MASIPAG.

Banuri, Tariq, Frédérique Apffel-Marglin, and World Institute for Development Economics Research, ed. 1993. Who will save the forests? knowledge, power, and environmental destruction. London; Atlantic Highlands, N.J., U.S.A: Zed Books.

Benkler, Yochai. 2003. The political economy of commons. Upgrade: The European Journal for the Informatics Professional 4: 6-9.

Benkler, Yochai. 2006. The wealth of networks: How social production transforms markets and freedom. Yale University Press.

Berkes, Fikret, Johan Colding, and Carl Folke. 2000. Rediscovery of Traditional Ecological Knowledge as Adaptive
Management. Ecological Applications 10: 1251-1262. https:// doi.org/10.1890/1051-0761(2000)010[1251:ROTEKA]2.0.CO;2.

Boyle, James. 2003. The Second Enclosure Movement and the Construction of the Public Domain. Law and Contemporary Problems 66: 33-74. https://doi.org/10.2139/ssrn.470983.

Buchanan, James M. 1965. An Economic Theory of Clubs. Economica 32: 1. https://doi.org/10.2307/2552442.

Calvet-Mir, Laura, Petra Benyei, Laura Aceituno-Mata, Manuel Pardode-Santayana, Daniel López-García, María Carrascosa-García, Antonio Perdomo-Molina, and Victoria Reyes-García. 2018. The Contribution of Traditional Agroecological Knowledge as a Digital Commons to Agroecological Transitions: The Case of the CONECT-e Platform. Sustainability. https://doi.org/10.3390/ su 10093214.

Chable, Véronique., Edwin Nuijten, Ambrogio Costanzo, Isabelle Goldringer, Riccardo Bocci, Bernadette Oehen, Frédéric. Rey, Dionysia Fasoula, Judit Feher, Marjo Keskitalo, Beate Koller, Michalis Omirou, Pedro Mendes-Moreira, Gaëlle. van Frank, Abdel Kader Naino. Jika, Mathieu Thomas, and Adanella Rossi. 2020. Embedding Cultivated Diversity in Society for Agro-Ecological Transition. Sustainability 12: 784. https://doi.org/10.3390/su12030784.

Cole, Daniel H. 2014. Learning von Lin: Lessons and Cautions from the Natural Commons for the Knowledge Commons. In Governing Knowledge Commons, ed. Brett M. Frischmann, Michael J. Madison, and Katherine Jo Strandburg, 45-68. Oxford; New York: Oxford University Press.

Coomes, Oliver T., Shawn J. McGuire, Eric Garine, Sophie Caillon, Doyle McKey, Elise Demeulenaere, Devra Jarvis, Guntra Aistara, Adeline Barnaud, Pascal Clouvel, Laure Emperaire, Sélim. Louafi, Pierre Martin, François Massol, Marco Pautasso, Chloé Violon, and Jean Wencélius. 2015. Farmer seed networks make a limited contribution to agriculture? Four common misconceptions. Food Policy 56: 41-50. https://doi.org/10.1016/j.foodpol.2015.07.008.

Cox, Michael, Gwen Arnold, and Sergio Villamayor Tomás. 2010. A review of design principles for community-based natural resource management. Ecology and Society 15: 38. https://doi.org/10.5751/ ES-03704-150438.

Dedeurwaerdere, Tom. 2012. Design principles for successful geneticresource commons for food and agriculture. International Journal for Ecological Economics and Statistics 26: 31-46.

Demeulenaere, Elise. 2005. HERBES FOLLES ET ARBRES ROIS Gestion paysanne des ligneux au pays konso (Ethiopie), contribution à la définition d'un patrimoine naturel. Anthropologie sociale et ethnologie: Museum national d'histoire naturelle - MNHN PARIS.

Demeulenaere, Elise. 2014. A political ontology of seeds: The transformative frictions of a farmers' movement in Europe. Journal of Global and Historical Anthropology 69: 45-61.

Demeulenaere, Elise. 2018. 'Free our seeds!' Strategies of farmers' movements to reappropriate seeds. In The Commons, Plant Breeding and Agricultural Research Challenges for Food Security and Agrobiodiversity, ed. Fabien Girard and Christine Frison.

Dutfield, Graham. 2018. Farmers, Innovation, and Intellectual Property: Current Trends and their Consequences for Food Security. In The commons, plant breeding and agricultural research: challenges for food security and agrobiodiversity., ed. Fabien Girard and Christine Frison. New York: Routledge.

Edelman, Marc. 2014. Food sovereignty: forgotten genealogies and future regulatory challenges. The Journal of Peasant Studies 41 (6): 959-978. https://doi.org/10.1080/03066150.2013.876998.

Engel, Christoph. 2002. Die soziale Funktion des Eigentums. In Bericht zur Lage des Eigentums, 9-107. Berlin.

Euler, Johannes. 2018. Conceptualizing the Commons: Moving Beyond the Goods-based Definition by Introducing the 
Social Practices of Commoning as Vital Determinant. Ecological Economics 143: 10-16. https://doi.org/10.1016/j.ecole con.2017.06.020.

Euler, Johannes, Britta Acksel, and Stephan Hankammer. 2020. Practice Turn in der Commons-Forschung: Von Substanz zu Prozess. Ökologisches Wirtschaften 1: 28-29.

Frischmann, Brett M., Michael J. Madison, and Katherine Jo Strandburg, ed. 2014. Governing Knowledge Commons. Oxford; New York: Oxford University Press.

Frison, Christine. 2016. Towards Redesigning the Plant Commons: A Critical Assessment of the Multilateral System of Access and Benefit-sharing of the International Treaty on Plant Genetic Resources for Food and Agriculture. Doctor in Law, Louvain: Université catholique de Louvain.

Frison, Christine. 2018. Planting the Commons: Towards Redesigning an Equitable Global Seed Exchange. In The commons, plant breeding and agricultural research: challenges for food security and agrobiodiversity, ed. Fabien Girard and Christine Frison. New York: Routledge.

Frison, Christine, Francisco López, and J. T. Esquinas-Alcazar, ed. 2011. Plant genetic resources and food security: stakeholder perspectives on the international treaty on plant genetic resources for food and agriculture. Issues in Agricultural Biodiversity. London; New York: Earthscan, FAO, Biodiversity International.

Galluzzi, Gea, Michael Halewood, Isabel López. Noriega, and Ronnie Vernooy. 2016. Twenty-five years of international exchanges of plant genetic resources facilitated by the CGIAR genebanks: a case study on global interdependence. Biodiversity and Conservation 25: 1421-1446. https://doi.org/10.1007/s10531-016-1109-7.

Girard, Fabien. 2018. Composing the Common World of the Local BioCommons in the Age of the Anthropocene. In The commons, plant breeding and agricultural research: challenges for food security and agrobiodiversity, ed. Fabien Girard and Christine Frison.

Halewood, Michael. 2013. What kind of goods are plant genetic resources for food and agriculture? Towards the identification and development of a new global commons. International Journal of the Commons 7: 278-312. https://doi.org/10.18352/ijc.412.

Halewood et al. 2020. Enhancing farmers' agency in the global crop commons through use of biocultural community protocols. Symposium: Seed as a commons-exploring innovative concepts and practices of governing seed and varieties. Agriculture and Human Values.

Hardin, Garrett. 1968. The Tragedy of the Commons*. Science 162: 1243-1248.

Helfrich, Silke. 2012. Commons: Für eine neue Politik jenseits von Markt und Staat. Edited by Heinrich-Böll-Stiftung. Bielefeld: transcript.

Heller, Michael A. 1998. Can Patents Deter Innovation? The Anticommons in Biomedical Research. Science 280: 698-701. https://doi. org/10.1126/science.280.5364.698.

Hess, Charlotte. 2012. The Unfolding of the Knowledge Commons. St Antony's International Review 8 (1): 13-24.

Hess, Charlotte, and Elinor Ostrom. 2003. Ideas, artefacts and facilities: information as a common-pool-resource. Law and Contemporary Problems 66: 111-145.

Hess, Charlotte, and Elinor Ostrom (eds.). 2007. Understanding knowledge as a commons: from theory to practice. Cambridge, Mass.: MIT Press.

Kliem, Lea, and Julia Tschersich. 2017. Defining central concepts for the RightSeeds Project. Working Paper I.

Kostakis, Vasilis, and Michel Bauwens. 2014. Network society and future scenarios for a collaborative economy. Palgrave Pivot. Basingstoke: Palgrave Macmillan.

Kultursaat e.V. 2017. Einblicke in das Jahr 2016.

Kultursaat e.V. 2018. Leitende Grundsätze.
Kultursaat e.V. 2019a. Einblicke 2018 - Jahresbericht Kultursaat e.V. Kultursaat e.V. 2019b. Die Sorten.

Kultursaat e.V. 2019c. Berufsbegleitende Fortbildung biologischdynamische Gemüsezüchtung.

van Laerhoven, Frank, and Elinor Ostrom. 2007. Traditions and Trends in the Study of the Commons. International Journal of the Commons 1: 3-28.

Louafi, Sélim, and Daniele Manzella. 2018. The Benefit Sharing Mechanisms under the International Treaty: Heterogeneity and Equity in Global Resources Management. In The commons, plant breeding and agricultural research: challenges for food security and agrobiodiversity, ed. Fabien Girard and Christine Frison. New York: Routledge.

MASIPAG. 2019. About MASIPAG.

Mazé, Armelle, Aida Calabuig Domenech, and Isabelle Goldringer. 2020. Commoning the seeds: alternative models of collective action and open innovation for recreating local knowledge commons. Agriculture and Human Values Symposium Issue on Seed Commons.

Müller, Christina. 2012. Practicing Commons in Community Gardens: Urban Gardening as a Corrective for Homo Economicus. In The Wealth of the Commons. A World beyond Market and State, ed. David Bollier and Silke Helfrich, 219-224.

Nightingale, Andrea J. 2019. Commoning for inclusion commons, exclusion, property and socio-natural becomings. International Journal of the Commons 13: 16-35. https://doi.org/10.18352/ ijc. 927.

Osman, A. M., and Veronique Chable. 2009. Breeding initiatives of seeds of landraces, amateur varieties and conservation varieties: an inventory and case studies. Louis Bolk Instituut [etc.].

Ostrom, Elinor. 1990. Governing the commons: the evolution of institutions for collective action. Canto Classics. Cambridge: Cambridge University Press.

Ostrom, Elinor. 2009. A General Framework for Analyzing Sustainability of Social-Ecological Systems. Science 325: 419-422.

Ostrom, Elinor. 2010. Polycentric systems for coping with collective action and global environmental change. Global Environmental Change 20: 550-557.

Patel, R. 2009. Food sovereignty. The Journal of Peasant Studies 36 (3): 663-706. https://doi.org/10.1080/03066150903143079.

Pautasso, Marco, Guntra Aistara, Adeline Barnaud, Sophie Caillon, Pascal Clouvel, Oliver T. Coomes, Marc Delêtre, et al. 2013. Seed exchange networks for agrobiodiversity conservation. A review. Agronomy for Sustainable Development 33: 151-175. https://doi. org/10.1007/s13593-012-0089-6.

Rathwell, Kaitlyn Joanne, Derek Armitage, and Fikret Berkes. 2015. Bridging knowledge systems to enhance governance of the environmental commons: A typology of settings. International Journal of the Commons 9: 851-880.

Reyes-Garcia, Victoria, Petra Benyei, and Laura Calvet-Mir. 2018. Traditional agricultural knowledge as a commons. In Routledge Handbook of Food as a Commons, ed. Jose Luis Vivero Pol, Tomaso Ferrando, Olivier de Schutter, and Ugo Mattei, 1st ed., 408. Routledge.

Sato, Chizu, and Jozelin María Soto. Alarcón. 2019. Toward a postcapitalist feminist political ecology' approach to the commons and commoning. International Journal of the Commons 13: 36. https ://doi.org/10.18352/ijc.933.

Sievers-Glotzbach, Stefanie, Julia Tschersich, Nina Gmeiner, Lea Kliem, and Anoush Ficiciyan. 2020. Diverse Seeds - Shared Practices: Conceptualizing Seed Commons. International Journal of the Commons. Forthcoming 14 (1): 418-438. https://doi. org/10.5334/ijc. 1043 .

Tummers, Lidewij, and Sherilyn MacGregor. 2019. Beyond wishful thinking a FPE perspective on commoning, care, and the promise 
of co-housing. International Journal of the Commons 13: 62. https ://doi.org/10.18352/ijc.918.

Tsioumani, Elsa. 2018. Beyond access and benefit-sharing: Lessons from the law and governance of agricultural biodiversity. The Journal of World Intellectual Property. https://doi.org/10.1111/ jwip.12094.

Vivero-Pol, Jose Luis. 2017. Food as Commons or Commodity? Exploring the Links between Normative Valuations and Agency in Food Transition. Sustainability 9: 442. https://doi.org/10.3390/ su9030442.

Vivero-Pol, Jose Luis. 2017. The idea of food as commons or commodity in academia. A systematic review of English scholarly texts. Journal of Rural Studies 53: 182-201. https://doi.org/10.1016/j. jrurstud.2017.05.015.

Vivero Pol, Jose Luis, Tomaso Ferrando, Olivier De Schutter, and Ugo Mattei. 2018. Introduction - the Commons Are Coming. In Routledge Handbook Of Food As A Commons: Expanding Approaches, ed. Jose Luis. Vivero-Pol, Tomaso Ferrando, Olivier De Schutter, and Ugo Mattei. Routledge.

Weiss, Kristen, Mark Hamann, and Helene Marsh. 2013. Bridging Knowledges: Understanding and Applying Indigenous and Western Scientific Knowledge for Marine Wildlife Management. Society \& Natural Resources 26: 285-302. https://doi. org/10.1080/08941920.2012.690065.

Wilbois, Klaus-Peter, and Monika Messmer. 2016. Umfrage zu Bedarfen in der ökologischen Pflanzenzüchtung. Forschungsinstitut für biologischen Landbau (FiBL).

Wolter, Hendrik, and Stefanie Sievers-Glotzbach. 2019. Bridging traditional and New Commons: The case of fruit breeding. International Journal of the Commons 13: 303. https://doi.org/10.18352 lijc.869.

Publisher's Note Springer Nature remains neutral with regard to jurisdictional claims in published maps and institutional affiliations.

Stefanie Sievers-Glotzbach is junior professor at the University of Oldenburg, Department of Business Administration, Economics and Law, and leads the research group RightSeeds, funded by the German Federal Ministry of Education and Research (BMBF). She holds a Ph.D. in Sustainability Sciences and a Diploma degree in Environmental Sciences, both from Leuphana University, Lüneburg. She was a researcher in the Ecological Economics group at Oldenburg University from 2012 to 2015, and the coordinator of the master program 'Sustainability Economics and Management'. Her research interests include ecological, institutional and sustainability economics, sustainable development, environmental justice, and socio-ecological resilience research. Her present research focusses on commons as a governance model and its potential for social-ecological transformation.

Johannes Euler is research assistant at Alanus University of Arts and Social Sciences and an active member in the Commons-Institute. He wrote his economic doctoral dissertation about conflicts in water management and potentials and problems of commoning in this field. His main research areas are Commons, Degrowth, Sustainability, Pluralism in Economics and Social-ecological Transformations.

Christine Frison is a FNRS Postdoctoral Legal Researcher at the Centre for Philosophy of Law from UCLouvain, where she is also a member of the Louvain Partnership Research on Ecological and Social Transition. She specialized in international environmental issues, in particular biodiversity and agrobiodiversity law and governance. She is an Associate Research Fellow at the Government \& Law Research Group from the University of Antwerp. She has taught international environmental law at the Universite Libre de Bruxelles and the University of Antwerp. Christine earned her joint-Ph.D. from UCLouvain \& KU Leuven (cosupervision Profs. Tom Dedeurwaerdere, Olivier De Schutter and Geertrui Van Overwalle), for which she received several prizes. Since 2004, she has been a Legal Research Fellow with the Centre for International Sustainable Development Law (McGill, Montreal, Canada).

Nina Gmeiner is a researcher in the project RightSeeds at the University of Oldenburg. She is currently writing her $\mathrm{PhD}$ about the connection of well-being and ownership regimes of seeds. After finishing her Masters of "Sustainability Economics and Management" in Oldenburg with a thesis on networking strategies of community supported agricultures, she worked in the research project "Nascent" on the transformative potential of alternative food initiatives before taking on her current position.

Lea Kliem is a researcher at the Institute for Ecological Economy Research (IÖW) in Berlin, member of the research group RightSeeds and a $\mathrm{PhD}$ candidate at the Carl von Ossietzky University Oldenburg. She holds an MSc in Nature, Society and Environmental Policy from the University of Oxford. Her research interests include socio-ecological systems and resilience, agricultural- and food policy and sustainable land use.

Armelle Mazé was trained as an institutional economist at the Université Paris I Panthéon-Sorbonne in France. She is currentlty Senior Research Fellow in Economics at the French Institut National de Recherche pour l'Agriculture, l'alimentation et l'Environnement (INRAE UMR SADAPT). Her current research deals with sustainability strategies and regulatory governance in EU policy.

Julia Tschersich is a researcher and $\mathrm{PhD}$ student in the project RightSeeds at the University of Oldenburg. Her dissertation examines how Seed Commons are affected by the complex Multi-Level Governance system around seeds, biodiversity and Intellectual Property Rights. Previously, she obtained a Master degree in 'Sustainability Economics and Management' at the University of Oldenburg and a Bachelor degree in 'International Relations' at the Technical University of Dresden. Her main research interests lie in the fields of Social-Ecological Transformation, Environmental Governance, Institutional Change, Degrowth, Social Movements and (Seed) Commons. 